\title{
Nimbolide Inhibits Cell Survival and Proliferation of IGF1 Mediated PI3K-Akt and MAPK Signaling in Human Breast Cancer Cells and TNF-A/TNFR1 Mediated Signaling Molecules in Prostate Cancer
}

\author{
Arunakaran J ${ }^{1 *}$, Elumalai $\mathrm{P}^{2}$ and Raja Singh $\mathrm{P}^{3}$ \\ ${ }^{1}$ Meenakshi Academy of Higher Education and Research, India \\ ${ }^{2,3}$ Department of Endocrinology, University of Madras, India
}

Submission: March 08, 2017; Published: April 19, 2017

*Corresponding author: Arunakaran J, Meenakshi Academy of Higher Education and Research, West KK Nagar, Chennai, India, Email: arunendo2014@gmail.com

\section{Introduction}

Nimbolide was first derived from the leaves and flowers of need. Neem Azadirachtaindica is a traditional medicinal plant of the Meliaceaefamily widely distributed in Asia, Africa and other tropical parts for the world. Studies of extracts from leaves, flowers, fruits and seeds have shown promising chemo preventive and therapeutic effects in pre-clinical research [1-2]. Demonstrated that extracts of Neem leaf have been reported to be non-toxic and non-mutagenic and are found to possess immunomodulatory as well as anti-inflammatory and anti-carcinogenic properties. Anticancer effects of ethanolic Neem leaf extracts on prostate cancer cell line have also been studied in our laboratory [3]. Our previous studies also demonstrated that induction of apoptosis and inhibition of PI3K/Akt pathway in androgen dependent and androgen independent prostate cancer cells by ethanolic Neem leaf extract [4]. Ethanolic Neem leaf extract induces apoptosis and inhibits the IGf signaling pathway in breast cancer cell line [5].

Nimbolide (5,7,4'-trihydroxy-3',5'-diprenylflavanone) a tetranortriterpenoid, consists of a classical limuloid skeleton with an $\alpha, \beta$-unsaturated ketene system and a $\delta$-laconic ring [6]. Literature evidence reveals that $\alpha, \beta$ unsaturated ketene structural element is responsible for the anti-cancer activity of Nimbolide [7].

Breast cancer is the leading cause of cancer related deaths in women. The incidence of breast cancer is on the rise and rapidly becoming the number one cancer in women. The insulin like growth factor (IGF) system is involved in the proliferation, survival and migration of tumor cells. IGF-1 receptor is a receptor tyrosine kinase that is over expressed in about $70 \%$ of breast cancer. It is established that the consequences of IGF1R activation by its legends result in the recruitment of major adopter signaling protein such as Src/ Collagen homology protein, which leads to interaction with Grb2/
SOS [8]. Recruitment of these molecules activates two distinct signal transduction pathways. One pathway activates Ras, Raf and mitogen activated protein kinase resulting in the transcription of genes that derives proliferation. The other pathway involves phosphoinositide [3]. Kinase (PI3K)/Akt that is responsible for cell survival and antiapoptotic signal transduction [9]. Interruption of IGF signaling has been shown to inhibittumor growth, block metastasis and enhance the effects of other forms of cancer treatment [10]. proved that Nimbolide strongly inhibited the growth of both estrogen positive and negative breast cancer cells by down regulating IGF signaling molecules. The blockage of IGF1R has been shown it inhibit cell proliferation and cell survival of breast cancer cells. They proved that Nimbolide is a potent inhibitor of IGF1R/Akt/ERK signaling. This growth inhibition was associated with accumulation of G0/G1 cell population and shown regulation of cycling protein expression.

Prostate cancer is a major public health problem worldwide. Pro-inflammatory cytokine TNF- $\alpha$ plays an important role in various physiological and pathological process including cell proliferation, apoptosis, immunity and inflammation produced by many types of cells. TNF Receptor 1 (TNFR1) and Receptor 2 (TNFR2) results in recruitment of signal transducer that activate at least three distinct effectors and is arguably the most potent inducer of nuclear factor (NF)- $\kappa B$ [11-12]. Studied that member of the TNFR super family can send both survival and death signals to cells. The activation of TNFR1 or R2 alone stimulates NF- $\mathrm{KB}$, p38 and p42/44, MAPK pathways, that TNFR1 was the predominant receptor stimulating those signaling events [13].

Hildt \& Oess et al. [14], demonstrated that Grb2 is a tyrosine kinase adaptor protein novel binding partner of TNFR1 and is needed for TNF- $\alpha$ dependent activation of c-Raf- 1 kinase and the SH3 domains 
of Grb2 are known to interact with SOS protein which interfere with Ras [15]. Studied that GTP binding serine /heroine kinase protein Ras is the common upstream molecule of several signaling pathways like Raf/MEK/ERK [16]. Studied that Nimbolide treatment suppressed expression of TNF- $\alpha$, SODD, Grb2, SOS mRNA and modulated TNF- $\alpha$ / TNFR1 regulated NF- $\mathrm{KB}$ and MAPK signaling molecules in prostate cancer cell line (PC-3). Additional molecular dynamics stimulation studies confirmed the stability of Nimbolide and signaling molecules binding interaction. Binding pose analysis revealed the significance of hydrogen band interaction for effective stabilization of virtual Ligand protein complexes.

Nimbolide exerted anti-cancer effects in vitro by representing the PI3K/Akt/mTOR pathway in PC-3 cells [17]. Nimbolide inhibited prostate cancer cell survival and proliferation via NF- $\kappa$ Band MAPK pathways. Molecular and chemo preventive potential of Nimbolide in cancer has also been reviewed recently [5]. Thus Nimbolide decreases the proliferation of breast cancer cells by modulating the IGF singling molecules and inhibited prostate cancer cell survival and proliferation via NF- $\kappa B$, MAPK and PI3K-Akt pathways.

\section{Acknowledgement}

The financial assistance provided by the DST PURSE Phase II, New Delhi, is gratefully acknowledged (C.5/JRF- PURSE Phase II/ Endo/2014/663 dt16.12.14).

\section{References}

1. Paul R, Prasad M, Sah NK (2011) Anticancer biology of Azadirachta indica L (neem): a mini review. Cancer Biol Ther 12(6): 467-476.

2. Subapriya R, Nagini S (2005) Medicinal properties of Neem leaves: a review. Curr Med Chem Anticancer Agents 5(2): 149-146.

3. Kumar S, Suresh PK, Vijayababu MR, Arunkumar A, Arunakaran J, et al. (2006) Anticancer effects of ethanolic neem leaf extract on prostate cancer cell line (PC-3). J Ethnopharmacol 105(1-2): 246-250.

4. Gunadharini DN, Elumalai P, Arunkumar R, Senthilkumar K, Arunakaran J, et al. (2011) Induction of apoptosis and inhibition of PI3K/Akt pathway in PC-3 and LNCaP prostate cancer cells by ethanolic neem leaf extract. J Ethnopharmacol 134(3): 644-650.

5. Elumalai P, Arunkumar R, Benson CS, Govindaraj S, Arunakaran J, et al. (2014) Nimbolide inhibits IGF-I-mediated PI3K/Akt and MAPK signalling in human breast cancer cell lines (MCF-7 and MDA-MB-231). Cell Biochem Funct 32(5): 476-484.

6. Anitha G, Josepha Lourdu Raj J, Narasimhan S, Anand Solomon K, Rajan SS, et al. (2006) Nimbolide and isonimbolide. J Asian Nat Prod Res 8(5): 445-449.

7. Sastry BS, Suresh Babu K, Hari Babu T, Chandrasekhar S, Srinivas PV et al. (2006) Synthesis and biological activity of amide derivatives of nimbolide. Bioorg Med Chem Lett 16(16): 4391-4394.

8. Pollak MN, Schernhammer ES, Hankinson SE (2004) Insulin-like growth factors and neoplasia. Nat Rev Cancer 4(7): 505-518.

9. Manning BD, Cantley LC (2007) AKT/PKB signaling: navigating downstream. Cell 129(7): 1261-1274.

10. Elumalai P, Arunakaran J (2014) Review on molecular and chemopreventive potential of nimbolide in cancer. Genomics Inform 12(4): 156-164.

11. Aggarwal BB (2004) Nuclear factor-kappaB: the enemy within. Cancer Cell 6(3): 203-208.

12. Kawasaki H, Onuki R, Suyama E (2002) Identification of genes that function in the TNF-alpha-mediated apoptotic pathway using randomized hybrid ribozyme libraries. Nat Biotechnol 20(4): 376-380.

13. Amrani Y, Ammit AJ, Panettieri RA Jr (2001) Tumor necrosis factor receptor (TNFR) 1, but not TNFR2, mediates tumor necrosis factoralpha-induced interleukin- 6 and RANTES in human airway smooth muscle cells: role of p38 and p42/44 mitogen-activated protein kinases. Mol Pharmacol 60(4): 646-655.

14. Hildt $E$, Oess $S$ (1999) Identification of Grb2 as a novel binding partner of tumor necrosis factor (TNF) receptor I. J Exp Med 189(11): 17071714.

15. Yamamoto T, Taya S, Kaibuchi K (1999) Ras-induced transformation and signaling pathway. J Biochem 126(5): 799-803.

16. Raja Singh P, Priya ES, Balakrishnan S, Arunkumar R, Sharmila G, et al. (2016) Nimbolide inhibits androgen independent prostate cancer cells survival and proliferation by modulating multiple pro-survival signaling pathways. Biomed Pharmacother 84: 1623-1634.

17. Raja Singh P, Sugantha Priya E, Balakrishnan S, Arunkumar R, Sharmila G, et al. (2017) Inhibition of cell survival and proliferation by nimbolide in human androgen-independent prostate cancer (PC-3) cells: involvement of the PI3K/Akt pathway. Mol Cell Biochem 427(1-2): 6979.
Your next submission with Juniper Publishers will reach you the below assets

- Quality Editorial service

- Swift Peer Review

- Reprints availability

- E-prints Service

- Manuscript Podcast for convenient understanding

- Global attainment for your research

- Manuscript accessibility in different formats

( Pdf, E-pub, Full Text, Audio)

- Unceasing customer service

Track the below URL for one-step submission https://juniperpublishers.com/online-submission.php 